\title{
風荷重の動的成分が高減衰系積層ゴムの応答特性に与える影響に 関する実験的研究及びその解析モデルの検討 \\ EXPERIMENTAL STUDY ON INFLUENCE OF DYNAMIC COMPONENT OF WIND LOADING ON RESPONSE CHARACTERISTICS OF HIGH DAMPING RUBBER BEARINGS AND MODELING FOR WIND RESPONSE ANALYSIS
}

\author{
森 隆浩*, 加藤秀章**, 竹内貞光 ${ }^{* * *}$, 菊地隆志 ${ }^{* * * *}$, 室田伸夫***** \\ Takahiro MORI, Hideaki KATO, Sadamitsu TAKEUCHI, \\ Takashi KIKUCHI and Nobuo MUROTA
}

\begin{abstract}
In this study, wind response properties of high damping laminated rubber bearings (HDR) is investigated by experimental and analytical methods. According to the experimental result of HDR, horizontal creep deformation depends on magnitude of dynamic loading as well as that of static loading under the wind loading. This feature differs from other seismic isolation devices. Then we propose the simplified evaluation method and hysteresis model for time history response analysis under wind loading, which are established by taking account of the effect of creep deformation caused by dynamic loading. Firstly, we perform the wind loading test for high damping laminated rubber bearings and establish the simplified evaluation method and hysteresis model based on the test results. Next, we verify the validity of proposed models by comparing the analysis results with experimental results. Finally, we perform the time history response analysis using proposed hysteresis model.
\end{abstract}

Keywords : Seismic isolation, High damping laminated rubber bearings, Wind response, Creep, Hysteresis model, Time history response analysis 免震, 高減衰積層ゴム, 風応答, クリープ, 復元力モデル, 時刻歴応答解析

\section{1. はじめに}

近年、免震構造を採用した建築物の普及が進み、超高層建築物の 免震化の事例も数多く見られるようになった。こうした超高層建物 においては、台風などの風荷重の影響を受けやすく、風荷重を想定 した免震装置の健全性評価が必要となる。免震装置の代表例として、 復元力特性と減衰特性を併せ持つ高減衰積層ゴムや鉛挿入型積層ゴ ムが挙げられる。これらの免震装置は、減衰性能を持つという特徵 から、クリープ特性を示し、風荷重載荷時には時間と共に変形が増 大寸る恐れがある。過去、鉛挿入型積層ゴムにおいては、風応答に 対する様々な評価が実施され 1 ), 2)、簡易評価方法も提案されている 3)。一方、高減衰積層ゴムにおいても数例の試験評価が実施されて いるが 4), 5), 6)、高減衰積層ゴムは、鈆挿入型積層ゴムに比べ複雑な風 応答性状を示し、風応答における簡易評価方法が確立されていない。

本研究では、高減衰積層ゴムの風応答評価試験を実施し、その評 価結果を基に、風荷重下の最大せん断ひずみを予測する簡易評価方 法を提案する。本研究における高減衰積層ゴムの風応答評価試験の
結果、風荷重の静的成分一定の条件下で動的変動成分を変化させた 場合、動的変動成分が大きい程積層ゴムの水平クリープひずみが大 きくなる性質を示すことが明らかとなった。鉛挿入型積層ゴムにお いては、クリープ特性は静的成分のみに依存し、動的変動成分には 依らないことが知られており 3$)$ 、これは高減衰積層ゴム固有の性質 である。本研究において提案する簡易評価法は、動的変動成分によ るクリープ変形の効果を考慮に入れている。

超高層建物の風応答に対寸る健全性評価手法の 1 つに、時刻歴応 答解析が挙げられる。安井らはクリープ変形を伴う免震建物におけ る風応答時刻歴解析モデルの提案を行っている ${ }^{7)}$ 。しかしながら、 このモデルは静的成分に対するクリープ変形の影響しか考慮されて いない。このため、動的変動成分がクリープ変形に影響を与えると いう、高減衰積層ゴム固有の特性を再現できず、クリープ変形を適 切に評価することができない。過去、筆者らは有限要素法への適用 を目的とした高減衰積層ゴムのゴム材料の構成則として、変形履歴 積分型の弾塑性構成則を提案している ${ }^{8)}$ 。さらに、この構成則を単

\footnotetext{
本論文は参考文献13に示す日本建築学会大会学術講演会において発表したものを再考察し, 加筆しまとめたものである。

* (株ブリヂストンインフラ資材開発部＼cjkstart博士(理学)Ｉnfrastructure Products Dept., Bridgestone Co., Dr. Sci.

** (株ブリヂストンインフラ資材開発部 修士(理学)

*** (株ブリヂストンインフラ資材開発部 修士 (工学)

**** (株ブリヂストンインフラ資材開発部

***** (株ブリヂストンインフラ資材開発部 Ph. D 
純せん断変形へ適用することで、時刻歴応答解析のための復元力モ デルの提案も行っている9)。これらの変形履歷積分型の構成則や復 元力モデルは弾塑性モデルではあるが、過去の変形履歴に依存した クリープ特性を示すように考案されたモデルであり、動的変動成分 の影響を考慮できる。本研究では、この変形履歴積分型復元力モデ ルを用いた解析結果と実験結果を比較することで、モデルの妥当性 について検証する。また、提案した復元力モデルの風荷重時刻歴応 答解析を行い、その結果についても報告する。

\section{2．＼cjkstart高減衰積層ゴムの風応答特性評価実験}

高減衰積層ゴムにおける風荷重載荷時の特性を評価するために、 以下の 3 タイプの試験を行った。

（1）静的加力試験：1 方向に一定の水平荷重（静的せん断応力 $\tau_{\mathrm{s}}$ ) を与える静的な加力試験

（2）動的加力試験 : 1 方向一の一定の水平荷重（静的せん断応力 $\tau_{\mathrm{s}}$ ) に加えて、正弦波の繰り返し動的荷重（振幅土 $\tau_{\mathrm{d}}$ の動的せん断 応力）を与える動的な加力試験

（3）応答波加力試験: 風荷重時刻歴応答解析から得られた応答荷重 を入力として与えた動的な加力試験

試験概要及び試験結果を以下に示す。

\section{1 評価試験概要}

本実験に用いた評価試験体は、せん断弾性率 $G=0.620 \mathrm{MPa}$ 、等価 粘性減衰定数 $H_{\mathrm{eq}}=0.240$ の高減衰ゴム系積層ゴムとした ${ }^{10)}$ 。試験体 の形状を図 1 に、形状・性能一覧を表 1 に示す。また、静的加力試 験、動的加力試験、応答波加力試験の条件をそれぞれ表 2〜 4 に、 応答波加力試験における入力荷重の波形を図 2 に示す。静的加力試 験と動的加力試験においては、残留変形を評価するために、加力後 1 時間、水平荷重 0 で放置している。ただし、鉛直荷重については 水平荷重除荷後も載荷したままである。また、表 4 の応答波加力試 験において入力した応答波は、近藤ら 11)によって解析された風荷重 時刻歴応答解析の応答荷重結果のうち、免震システムとして鉛挿入 型積層ゴムを想定した粗度区分 II（応答荷重名 X-II）と III（応答 荷重名 X-III）における風向方向の応答結果とした。

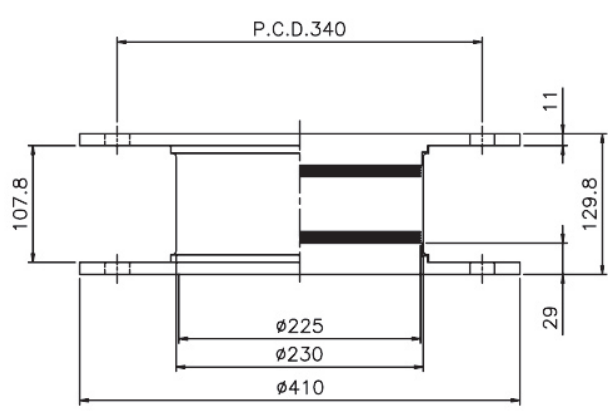

図 1 試験体の形状

試験装置の外観図を図 3 に、試験装置諸元を表 5 に示す。実験に 際しては、試験機のベアリング摩擦の影響を除外するため、摩擦の 影響を受けない位置に設置した分力計により水平荷重の計測・制御 を実施した。また、図 4 に示したように、実験中の積層ゴム表面温 度を非接触式温度計で計測した。静的加力試験及び動的加力試験に おいては、試験機と試験体の間には断熱材を設けていないが、応答
波加力試験においては断熱材を設けている。試験体は試験開始 24 時間以上前から、 $20^{\circ} \mathrm{C}$ 設定した恒温槽による保管を行い、試験中 の試験室は空調を $20^{\circ} \mathrm{C}$ に設定して試験を行った。

表 1 試験体形状・性能一覧

\begin{tabular}{|c|c|}
\hline 試験体数 & 2 \\
\hline ゴム外径 $/$ 内径 $(\mathrm{mm})$ & $\phi 225 / \phi 0$ \\
\hline ゴム 1 層厚さ $(\mathrm{mm})$ & 1.6 \\
\hline ゴム積層数 & 28 \\
\hline 内部鋼板厚さ $(\mathrm{mm})$ & 1.0 \\
\hline 1 次形状係数 $S_{1}$ & 35.2 \\
\hline 2 次形状係数 $S_{2}$ & 5.02 \\
\hline せん断弾性率 $(\mathrm{MPa})$ & 0.620 \\
\hline 水平剛性 $(\mathrm{kN} / \mathrm{mm})$ & 0.554 \\
\hline
\end{tabular}

※ せん断弾性率と水平剛性はせん断ひずみ $100 \%$ 時の性能を表す。

表 2 静的加力試験条件

\begin{tabular}{|c|c|c|c|c|}
\hline \multirow{2}{*}{ 試験体 } & $\begin{array}{c}\text { せん断応力 } \\
\tau_{\mathrm{s}} \pm \tau_{\mathrm{d}}(\mathrm{MPa})\end{array}$ & $\begin{array}{c}\text { 面圧 } \\
(\mathrm{MPa})\end{array}$ & $\begin{array}{c}\text { 加力時間 } \\
\text { (hour) }\end{array}$ & $\begin{array}{c}\text { 加力後放置 } \\
\text { 時間(hour) }\end{array}$ \\
\hline \hline \multirow{4}{*}{ No.1 } & $0.1 \pm 0.0$ & 15 & 2 & 1 \\
\cline { 2 - 5 } & $0.2 \pm 0.0$ & 15 & 2 & 1 \\
\cline { 2 - 5 } & $0.3 \pm 0.0$ & 15 & 2 & 1 \\
\cline { 2 - 5 } & $0.4 \pm 0.0$ & 15 & 2 & 1 \\
\hline
\end{tabular}

表 3 動的加力試験条件

\begin{tabular}{|c|c|c|c|c|c|}
\hline \multirow{2}{*}{ 試験体 } & $\begin{array}{c}\text { せん断応力 } \\
\tau_{\mathrm{s}} \pm \tau_{\mathrm{d}}(\mathrm{MPa})\end{array}$ & $\begin{array}{c}\text { 面圧 } \\
(\mathrm{MPa})\end{array}$ & $\begin{array}{c}\text { 周波数 } \\
(\mathrm{Hz})\end{array}$ & $\begin{array}{c}\text { 加力時間 } \\
\text { (hour) }\end{array}$ & $\begin{array}{c}\text { 加力後放置 } \\
\text { 時間(hour) }\end{array}$ \\
\hline \hline \multirow{3}{*}{ No.2 } & $0.2 \pm 0.05$ & 15 & 0.33 & 2 & 1 \\
\cline { 2 - 6 } & $0.2 \pm 0.1$ & 15 & 0.33 & 2 & 1 \\
\cline { 2 - 6 } & $0.2 \pm 0.2$ & 15 & 0.33 & 2 & 1 \\
\hline \multirow{3}{*}{ No2 } & $0.3 \pm 0.075$ & 15 & 0.33 & 2 & 1 \\
\cline { 2 - 6 } & $0.3 \pm 0.15$ & 15 & 0.33 & 2 & 1 \\
\cline { 2 - 6 } & $0.3 \pm 0.3$ & 15 & 0.33 & 2 & 1 \\
\hline \multirow{3}{*}{ No1 } & $0.4 \pm 0.1$ & 15 & 0.33 & 2 & 1 \\
\cline { 2 - 6 } & $0.4 \pm 0.2$ & 15 & 0.33 & 2 & 1 \\
\cline { 2 - 6 } & $0.4 \pm 0.4$ & 15 & 0.33 & 2 & 1 \\
\hline
\end{tabular}

表 4 応答波加力試験条件

\begin{tabular}{|c|c|c|c|c|c|}
\hline 試験体 & $\begin{array}{c}\text { 応答 } \\
\text { 荷重名 }\end{array}$ & $\begin{array}{c}\text { 最大応答荷重 } \\
(\mathrm{MPa})\end{array}$ & $\begin{array}{c}\text { 面圧 } \\
(\mathrm{MPa})\end{array}$ & $\begin{array}{c}\text { 加力時間 } \\
\text { (hour) }\end{array}$ & $\begin{array}{c}\text { 加力後放置 } \\
\text { 時間(hour) }\end{array}$ \\
\hline \hline \multirow{2}{*}{ No.2 } & X-III & 0.521 & 15 & 4.5 & 0 \\
\cline { 2 - 6 } & X-II & 0.673 & 15 & 4.5 & 0 \\
\hline
\end{tabular}

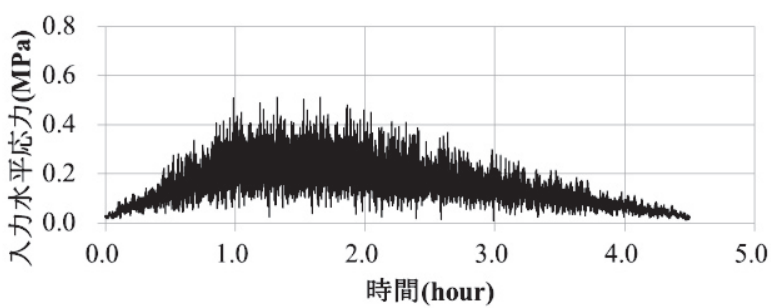

(a) X-III

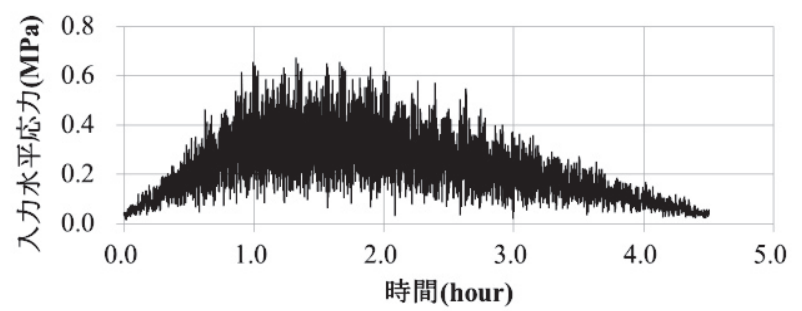

(b) X-II

図 2 応答波加力試験における加力波形 


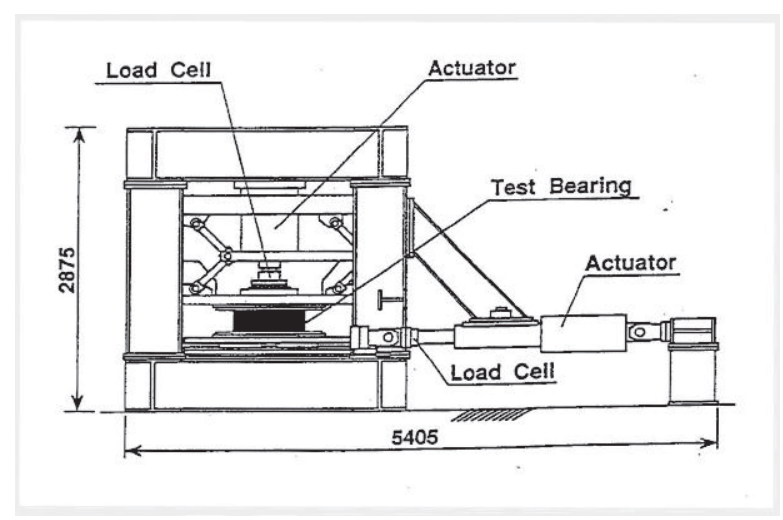

図 3 試験装置全体図

表 5 試験装置諸元

\begin{tabular}{|l|l|}
\hline 鉛直ストローク & $\pm 100 \mathrm{~mm}$ \\
\hline 鉛直荷重 (圧縮を正) & $-30 \sim+100 \operatorname{tonf}(-300 \sim 1000 \mathrm{kN})$ \\
\hline 鉛直クリアランス & $200 \mathrm{~mm}$ \\
\hline 水平ストローク & $\pm 300 \mathrm{~mm}$ \\
\hline 水平荷重 & $\pm 20 \operatorname{tonf}(200 \mathrm{kN})$ \\
\hline
\end{tabular}

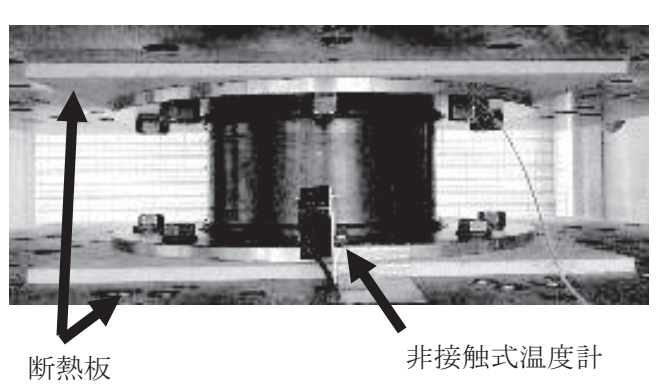

図 4 試験の様子

\section{2 評価試験結果}

静的加力試験におけるせん断応力-せん断ひずみ関係 $(\tau-\gamma$ 関係 $)$ の 結果を図 5 に示寸。図 5 からわかるように、時間とともにせん断ひ ずみが増大するクリープ現象が確認された。一般に、クリープひず みは弾性ひずみ（初期ひずみ）からの偏差として扱われる。しかし ながら、高減衰積層ゴムにおいては、弾性ひずみとクリープひずみ の境界が不明瞭であり、両者を区別することが難しい。そこで、本 論文では、弾性ひずみも含めた全ひずみ量によって、風荷重載荷時 の変形特性を議論する。図 5 に示したように、静的なせん断応力 $\tau_{\mathrm{s}}$ が大きい程、せん断ひずみ量が大きいことがわかる。また、せん断 ひずみ量は、 $\tau_{\mathrm{s}}$ に対して線形ではなく、 $\tau_{\mathrm{s}}$ が大きくなるにつれて非 線形に増大寸ることがわかる。除荷 1 時間後の残留ひずみについて は、 $\tau_{\mathrm{s}}=0.4 \mathrm{MPa}$ の場合でも $\gamma=0.1$ 程度である。一般的な積層ゴムのゴ 厶層厚さは $200 \mathrm{~mm}$ 程度であるので、 $\gamma=0.1$ を実際の建物における免 震層の変形量に換算すると $20 \mathrm{~mm}$ 程度であり、残留変形の影響は小 さいことがわかる。

動的加力試験におけるせん断ひずみの時間変化( $\gamma-t$ 関係)の結果を 図 6 に、 $\tau-\gamma$ 関係の結果を図 7 に、積層ゴム表面温度の時間変化を図 8 に示す。図 6、7 からわかるように、いずれの試験においてもクリ ープ挙動を示すが、 $\tau_{\mathrm{s}} \pm \tau_{\mathrm{d}}=0.4 \pm 0.4 \mathrm{MPa}$ を除いて比較的安定した変形
の増大が見られる。しかしながら、 $\tau_{\mathrm{s}} \pm \tau_{\mathrm{d}}=0.4 \pm 0.4 \mathrm{MPa}$ の場合は、時 間とともに変形量が急激に増大しており、不安定な挙動を示してい ることがわかる。これは、図 8 からもわかるように、 $\tau_{\mathrm{s}} \pm \tau_{\mathrm{d}}=0.4 \pm$ $0.4 \mathrm{MPa}$ の場合には、繰返し加力によって積層ゴムの温度が急激に上 昇し、その結果、積層ゴムの剛性が低下したことが原因と考えられ る。このような不安定挙動は、積層ゴムの内部温度と密接に関係し ており、急激な温度上昇を示すような風応答入力がある場合は、免 震建物の設計において、高減衰積層ゴムの適用範囲外とする必要が ある。

鋁挿入型積層ゴムにて動的加力試験を行った場合、クリープ特性 は静的成分（=静的せん断応力 $\tau_{\mathrm{s}}$ ) のみに依存し、動的成分（=動的 せん断応力 $\tau_{\mathrm{d}}$ ） が鉛プラグの繰返し熱履歴による降伏荷重低下のな い範囲であれば、動的成分には依らないということが従来の知見と してある ${ }^{3)}$ 。しかしながら、高減衰積層ゴムにおいては、図 6、7 か らわかるように、静的成分一定の条件下で動的成分を増加させたと き、動的成分の増大とともにせん断ひずみ量も増大している様子が わかる。本論文では、動的成分の増大に伴うこのような付加的せん 断ひずみを、「動的クリープ」と呼ぶこととする。竹中らは、風応答 によるせん断ひずみを、静的成分 $\gamma_{\mathrm{s}}$ と動的成分 $\gamma_{\mathrm{d}}$ に分離することに よる簡易評価手法の提案を行っている ${ }^{3)}$ 。静的成分 $\gamma_{\mathrm{s}}$ については、 図 5 に示した静的クリープ試験から予測し、動的成分 $\gamma_{\mathrm{d}}$ については、 積層ゴムのスケルトンカーブから応力が $\tau_{\mathrm{d}}$ となる点のせん断ひずみ として定める。 $\gamma_{\mathrm{s}}$ と $\gamma_{\mathrm{d}}$ の和を風応答における最大せん断ひずみとし て評価しているため、この評価手法では、高減衰積層ゴムの動的ク リープ変形による付加的な変形が考慮されていない。本論文 3 ．1 節にて、これらの動的クリープを考慮した高減衰積層ゴムの風荷重 下の最大せん断ひずみを予測する簡易評価法を提案する。

応答加力試験における $\gamma-t$ 関係を図 9 に、 $\tau-\gamma$ 関係を図 10 に、積層 ゴム表面温度の時間変化を図 11 に示す。図 $9 、 10$ からもわかるよう に、風荷重の増大とともにせん断ひずみが増大し、風荷重の減少と ともにせん断ひずみが減少している様子がわかる。応答波形 X-III に対しては、最大応答せん断ひずみ $\gamma=0.72 、$ 残留せん断ひずみ $\gamma=0.23$ だった。また、応答波形 X-II に対しては、最大応答せん断ひずみ $\gamma=1.18$ 、残留せん断ひずみ $\gamma=0.49$ だった。応答加力試験では、動的 加力試験で実施したような加力後の放置試験を実施していないが、 加力後の放置を考慮に入れると、残留変形はさらに小さくなると予 想される。また、図 11 からもわかるように、応答加力試験において は、積層ゴム表面の温度はほぼ一定であり、急激な温度上昇は観測 されなかった。

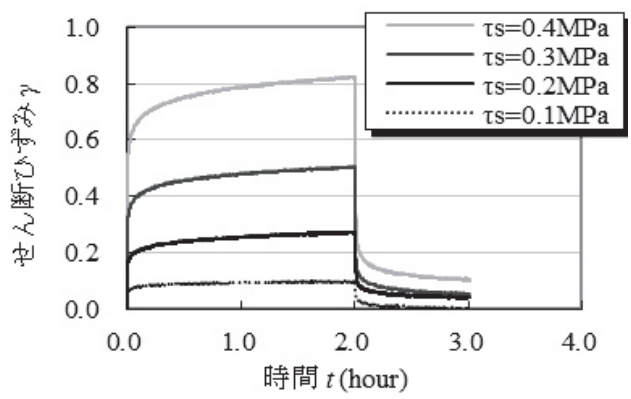

図 5 静的加力試験における $\gamma-t$ 関係 


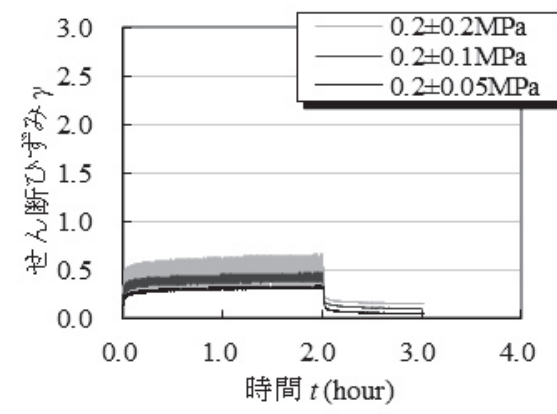

(a) $\tau_{\mathrm{s}}=0.2$

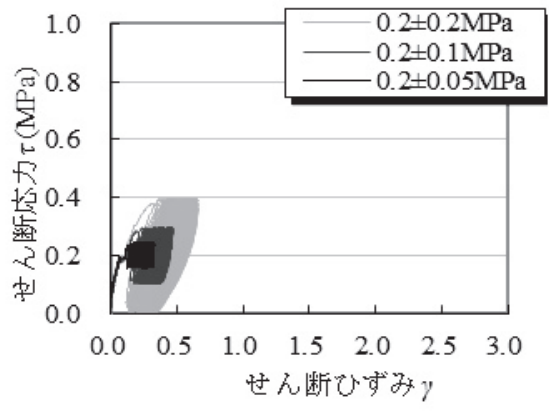

(a) $\tau_{\mathrm{s}}=0.2$

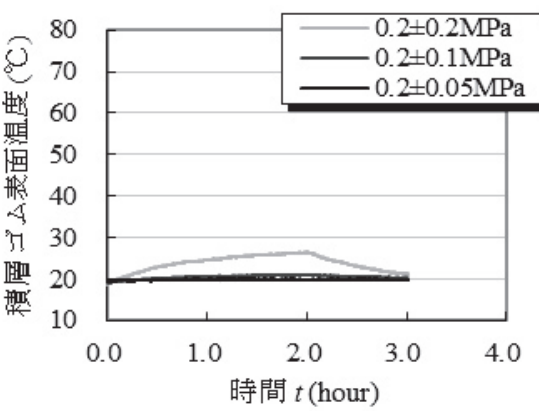

(a) $\tau_{\mathrm{s}}=0.2$

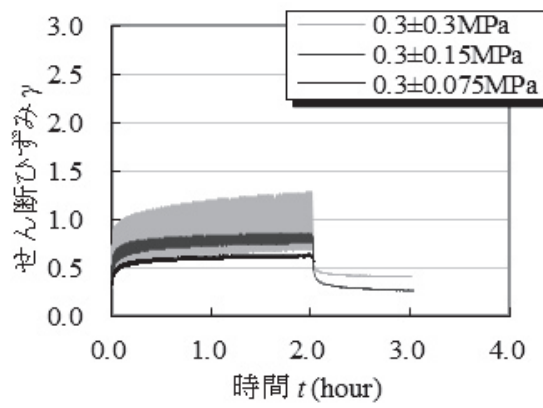

(b) $\tau_{\mathrm{s}}=0.3$

図 6 動的加力試験における $\gamma-t$ 関係

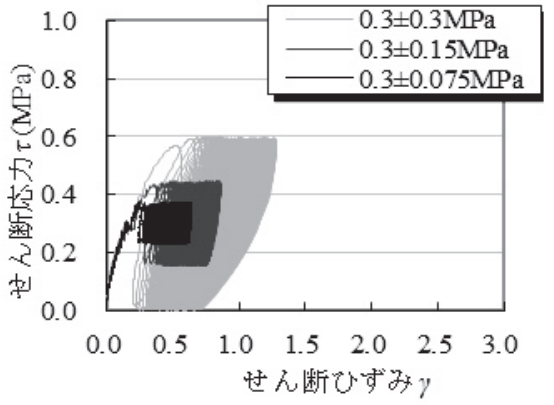

(b) $\tau_{\mathrm{s}}=0.3$

図 7 動的加力試験における $\tau-\gamma$ 関係

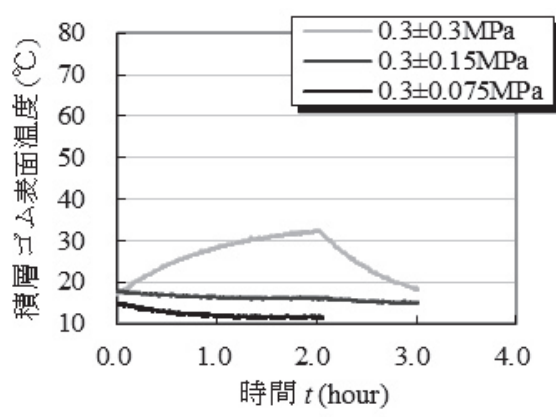

(b) $\tau_{\mathrm{s}}=0.3$

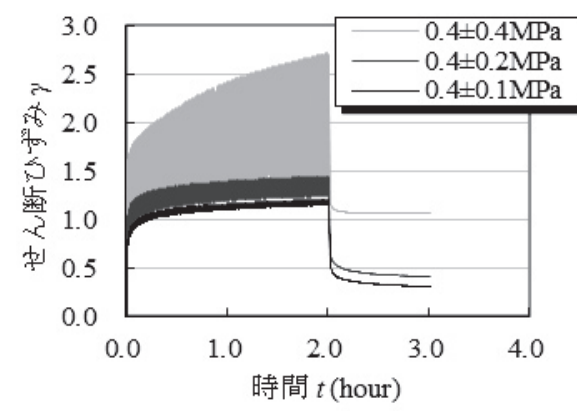

(c) $\tau_{\mathrm{s}}=0.4$

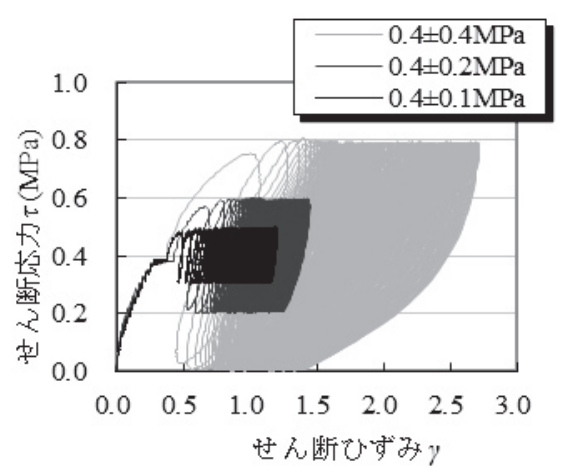

(c) $\tau_{\mathrm{s}}=0.4$

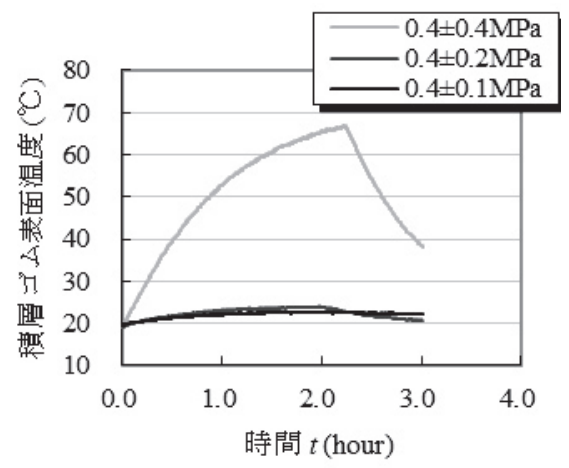

(c) $\tau_{\mathrm{s}}=0.4$

図 8 動的加力試験における表面温度の時間変化

$※ \tau_{\mathrm{s}} \pm \tau_{\mathrm{d}}=0.3 \pm 0.075(\mathrm{MPa})$ につては、試験機の不具合により動的加力後の 1 時間の放置試験を実施していない。 ※本試験は試験室温の空調を $20^{\circ} \mathrm{C}$ 設定した上で実施している。しかし、実際の室温が $20^{\circ} \mathrm{C} 下$ 回っていたために、積層ゴムの表面温度が 時間とともに低下するケースが見られた。

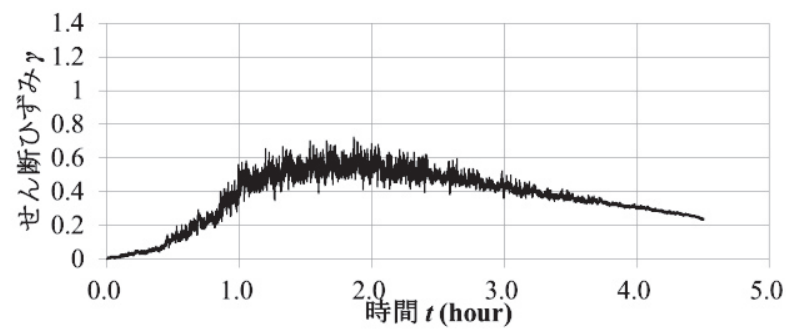

(a) X-III

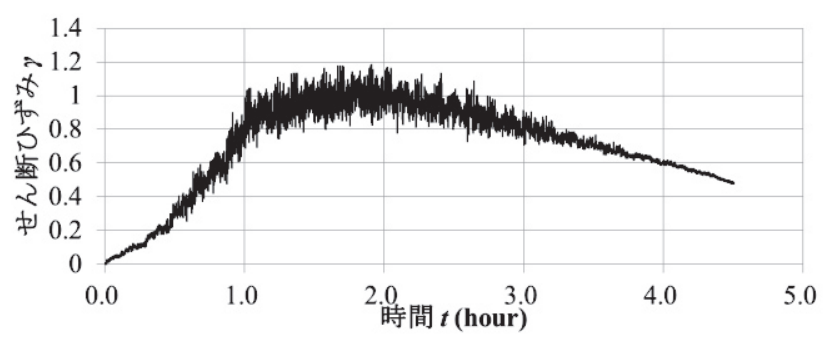

(b) X-II

図 9 応答波加力試験における $\gamma-t$ 関係 


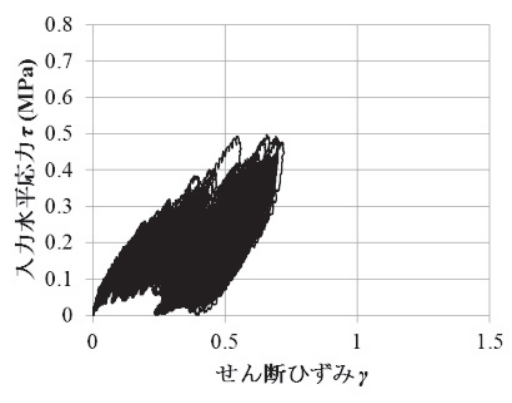

(a) $\mathrm{X}$-III

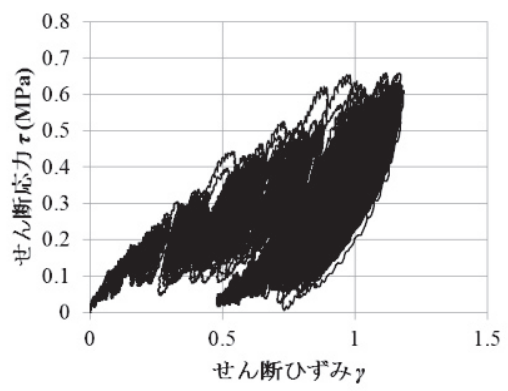

(b) X-II

図 10 応答波加力試験における $\tau-\gamma$ 関係

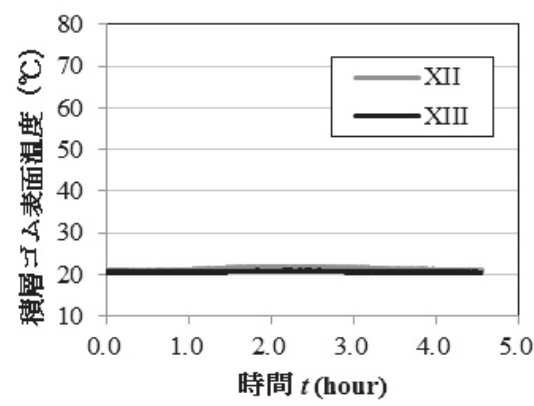

図 11 応答波加力試験における 表面温度の時間変化

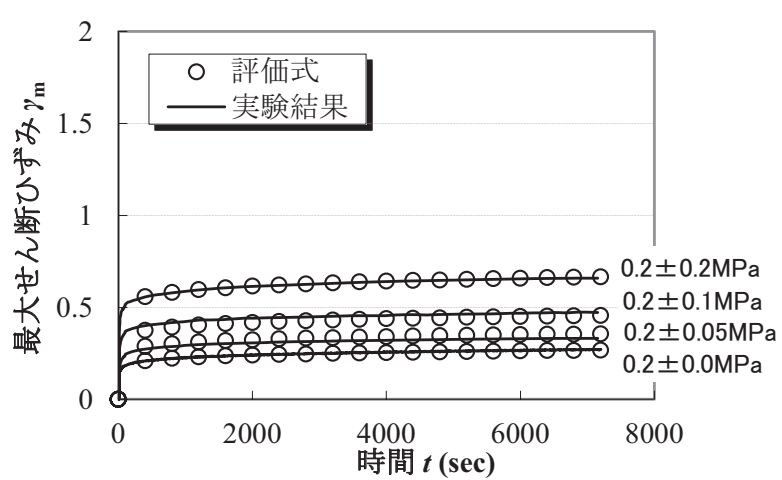

(a) $\tau_{\mathrm{s}}=0.2 \mathrm{MPa}$

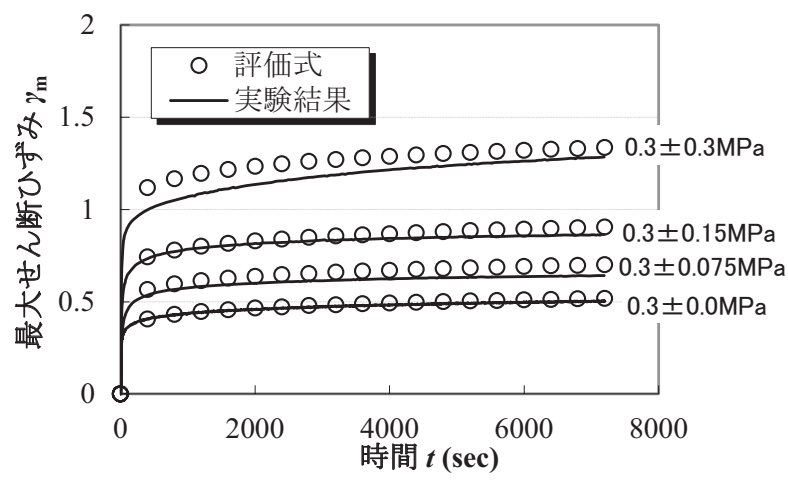

(b) $\tau_{\mathrm{s}}=0.3 \mathrm{MPa}$

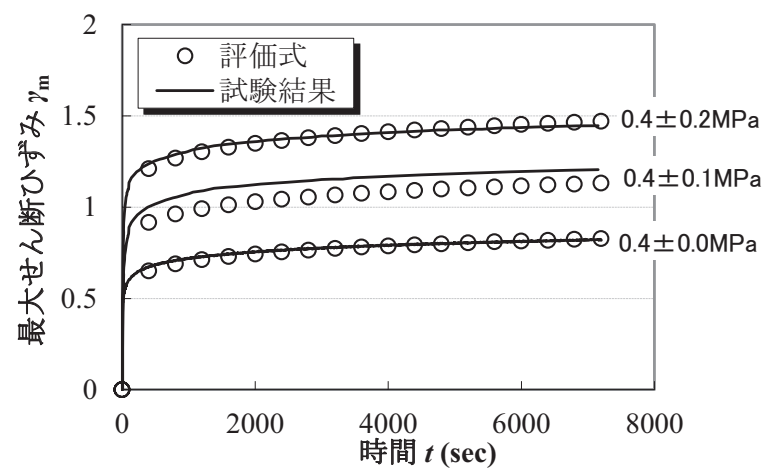

(c) $\tau_{\mathrm{s}}=0.4 \mathrm{MPa}$

図 12 評価式と試験結果の比較

\section{3. 解析モデルによる評価}

動的加力試験の結果、高減衰積層ゴムにおいては、動的な荷重振
幅がクリープ変形に影響を与えることが分かった。本章では、動的 荷重振幅の影響を考慮した、高減衰積層ゴムの風応答簡易評価法で ある「風荷重下の最大せん断ひずみ予測式」及び風荷重時刻歴応答 解析モデルを提案する。

\section{1 高減衰積層ゴムの風荷重下の最大せん断ひずみ予測式}

2 章で示したように、積層ゴムは、簡易的に風荷重を静的成分 $\tau_{\mathrm{s}}$ と動的成分 $\tau_{\mathrm{d}}$ に分離した加力実験を行い、最大せん断ひずみや残留 変形等の応答性状を評価する。その結果を基に、強風時に免震層に 極度の変形が生じないよう、建物を安全に設計する。この際、強風 時の最大変形量を予測できる簡易評価法があれば、建物の設計に有 用である。本章では、風荷重下の高減衰積層ゴムの変形特性を予測 する「最大せん断ひずみ予測式」を、風荷重の時間 $t(\mathrm{sec})$ 、静的せん 断応力 $\tau_{\mathrm{s}}(\mathrm{MPa})$ 、動的せん断応力 $\tau_{\mathrm{d}}(\mathrm{MPa})$ の関数として提案する。 2 . 2 節の「静的加力試験」及び「動的加力試験」の結果を基に、「動的 クリープ」を考慮した高減衰積層ゴムにおける風荷重下の最大せん 断ひずみの予測式を、以下に示す。

$$
\gamma_{\mathrm{m}}\left(\tau_{\mathrm{s}}, \tau_{\mathrm{d}}, t\right)=C_{1} t^{p_{1}} \tau_{\mathrm{s}}^{q_{1}}+C_{2} t^{p_{2}} \tau_{\mathrm{s}}^{q_{2}} \tau_{\mathrm{d}}^{r_{2}}
$$

$\gamma_{\mathrm{m}}$ は「動的加力試験」において応力振幅 $\tau_{\mathrm{d}}$ の動的せん断応力を与え た時、 1 サイクル中に経験する最大せん断ひずみである。右辺第 1 項が静的に一定水平荷重を与えた場合のクリープを考慮した変形特 性を表す項であり、右辺第 2 項が動的クリープも考慮するために追 加された項である。 $C_{1} 、 C_{2} 、 p_{1} 、 p_{2} 、 q_{1} 、 q_{2} 、 r_{2}$ は「静的加力試験」 及び「動的加力試験」の結果から決めるパラメータである。 2.2 節における試験結果に合うように、各パラメータを表 6 の通り決定 した。また、不安定挙動を示した $\tau_{\mathrm{s}}^{ \pm} \tau_{\mathrm{d}}=0.4 \pm 0.4(\mathrm{MPa})$ を除く試験結 果と評価式(2.1)の比較を図 12 に示す。評価式と試験結果が概ね合っ ていることがわかる。

表 6 評価式におけるパラメータ

\begin{tabular}{|c|c|c|c|c|c|c|}
\hline$C_{1}$ & $C_{2}$ & $p_{1}$ & $p_{2}$ & $q_{1}$ & $q_{2}$ & $r_{2}$ \\
\hline 1.76 & 4.50 & 0.0831 & 0.0481 & 1.63 & 0.691 & 1.08 \\
\hline
\end{tabular}

\section{2 解析モデル概要}

本節では、高減衰積層ゴムの風応答時刻歴解析のための復元力モ デルを提案する。モデルは、筆者らによって提案した変形履歴積分 型の復元力モデルを基本とした ${ }^{9)}$ 。本研究にて提案する復元力モデ 
ルのせん断応力ーせん断ひずみ式（ $\tau-\gamma$ 関係式）を以下に示す。

$$
\begin{aligned}
& \tau(\gamma)=a W(\gamma) \gamma+\sum_{i=1}^{3} g_{i} \int_{0}^{\gamma} e^{-\left(\Gamma-\Gamma^{\prime}\right) \Lambda_{i}}\left(\gamma^{\prime 2}-\frac{2}{3} \gamma \gamma^{\prime}+1\right) \mathrm{d} \gamma^{\prime} \\
& \Gamma=\Gamma(\gamma)=\int_{0}^{\gamma}|\mathrm{d} \gamma| \\
& W(\gamma)=\theta+(1-\theta) \exp \left(-\gamma_{\max } / \beta\right)
\end{aligned}
$$

「はせん断ひずみの変化量の累積值を表す。即ち、せん断ひずみ $100 \%$ の変形を 1 サイクル与えた場合には $\Gamma=4$ であり、単調加力した 場合には $\Gamma=\gamma$ となる。 $W(\gamma)$ はゴムが大変形を受けた際の剛性低下を 表現するためのダメージ関数であり、過去に受けた最大せん断ひず み $\gamma_{\max }$ の関数である。 $a, \theta, \beta, g_{1}, g_{2}, g_{3}, l_{1}, l_{2}, l_{3}$ は物性パラメータであ る。本式は、変形履歴積分型の弾塑性構成則から単純せん断ひずみ $\gamma$ を与えたときの $\tau-\gamma$ の関係式を導出し、さらに繰り返しによる剛性 低下を考慮するために、ダメージ関数 $W(\gamma)$ を付加したものである。 提案した復元力モデルの基本となる変形履歴積分型の弾塑性構成則 は、時間依存性は示さず、過去の変形履歴に依存して応力緩和特性 やクリープ的特性を示すのが特徵である。従って、提案した復元力 モデルも時間依存性がないため、静的な一定荷重を与えた場合には ひずみは一定であり、時間とともにひずみが増大するクリープ特性 は示さない。動的成分を与えて初めてクリープ的挙動を示すのが特 徵である。

式(3.1)〜(3.3)から明らかなように、提案されたモデルは温度の影 響を考慮していない。即ち、2 章の実験結果において温度の影響が 大きかった $\tau_{\mathrm{s}} \pm \tau_{\mathrm{d}}=0.4 \pm 0.4 \mathrm{MPa}$ のようなケースには適用できず、本提 案式は温度上昇の影響が小さい範囲で適用が可能である。温度上昇 は、積層ゴムの単位時間・単位体積当たりのエネルギー吸収量に直 接関係する。図 8(b)からわかるように、周期 $3 \mathrm{sec} 、 \tau_{\mathrm{s}} \pm \tau_{\mathrm{d}}=0.3 \pm 0.3 \mathrm{MPa}$ のケースであれば加力 2 時間後の温度上昇は $10^{\circ} \mathrm{C}$ 程度である。従っ て、周期 $3 \mathrm{sec} 、 \tau_{\mathrm{s}} \pm \tau_{\mathrm{d}}=0.3 \pm 0.3 \mathrm{MPa}$ における単位時間・単位体積当た りのエネルギー吸収量よりも小さい場合に、提案モデル式(3.1)〜 (3.3)は適用可能である。

式(3.1) (3.3)の各物性パラメータは、 $\tau_{\mathrm{s}} \pm \tau_{\mathrm{d}}=0.4 \pm 0.2(\mathrm{MPa})$ と $\tau_{\mathrm{s}} \pm \tau_{\mathrm{d}}$ $=0.2 \pm 0.05(\mathrm{MPa})$ の実験結果における $\tau-\gamma$ 関係に合うように值を定め

\begin{tabular}{|c|c|c|c|c|}
\hline $\begin{array}{c}a \\
(\mathrm{MPa})\end{array}$ & $\begin{array}{l}\theta \\
(-)\end{array}$ & $\begin{array}{l}\beta \\
(-)\end{array}$ & $\begin{array}{c}g_{1} \\
(\mathrm{MPa})\end{array}$ & $\begin{array}{c}g_{2} \\
(\mathrm{MPa})\end{array}$ \\
\hline 0.64 & 0.35 & 0.8 & 1.62 & 0.445 \\
\hline $\begin{array}{c}g_{3} \\
(\mathrm{MPa})\end{array}$ & $\begin{array}{l}l_{1} \\
(-)\end{array}$ & $\begin{array}{l}l_{2} \\
(-)\end{array}$ & $\begin{array}{l}l_{3} \\
(-)\end{array}$ & \\
\hline 0.06 & 0.0417 & 2.66 & 200 & \\
\hline
\end{tabular}
た。表 7 に同定した各物性パラメータの值を示す。

表 7 パラメータ值

式(3.1)〜(3.3)は水平 1 方向加力にみを考慮した復元力モデルであ るが、実際の風荷重においては風向方向のみでなく風向直交方向の 風荷重も問題となることがある。上式同様に変形履歴積分型の弾塑 性構成則より、単純せん断ひずみ $\gamma_{x}, \gamma_{y}$ を水平 2 方向に与えたときの $\tau_{x}\left(\gamma_{x}, \gamma_{y}\right), \tau_{y}\left(\gamma_{x}, \gamma_{y}\right)$ を導出し、1 方向加力の場合と同様のダメージ関数
を付加した 2 方向復元力モデルを以下に示す。

$$
\begin{aligned}
& \left\{\begin{array}{r}
\tau_{x}\left(\gamma_{x}, \gamma_{y}\right)=a W \gamma_{x}+\sum_{i=1}^{3} g_{i} \int_{0}^{\Gamma} e^{-\left(\Gamma-\Gamma^{\prime}\right) h_{i}} \frac{\mathrm{d}}{\mathrm{d} \Gamma^{\prime}}\left[\frac{1}{3}\left(\gamma_{x}^{\prime}-\gamma_{x}\right)\left(\gamma_{x}^{\prime 2}+\gamma_{y}^{\prime 2}\right)+\gamma_{x}^{\prime}\right] \mathrm{d} \Gamma^{\prime} \\
\tau_{y}\left(\gamma_{x}, \gamma_{y}\right)=a W \gamma_{y}+\sum_{i=1}^{3} g_{i} \int_{0}^{\Gamma} e^{-\left(\Gamma-\Gamma^{\prime}\right) h_{i}} \frac{\mathrm{d}}{\mathrm{d} \Gamma^{\prime}}\left[\frac{1}{3}\left(\gamma_{y}^{\prime}-\gamma_{y}\right)\left(\gamma_{x}^{\prime 2}+\gamma_{y}^{\prime 2}\right)+\gamma_{y}^{\prime}\right] \mathrm{d} \Gamma^{\prime} \\
\cdots(3.4)
\end{array}\right. \\
& \cdots=\int_{C} \sqrt{\mathrm{d} \gamma_{x}{ }^{2}+\mathrm{d} \gamma_{y}{ }^{2}} \\
& \cdots(3.5)
\end{aligned}
$$

「は変形開始から描いた 2 方向加力軌道の長さを表す。即ち、一定 のせん断ひずみ $\gamma$ で円軌道を 1 サイクル描いた場合は $\Gamma=2 \pi \gamma$ である。 式(3.4)〜(3.6)において、 $\gamma_{y}=\gamma, \gamma_{y}=0$ とした場合、式(3.1)〜(3.3)と一致 する。

\section{3 解析結果及び実験結果との比較}

動的加力試験及び応答波加力試験における、 $\gamma-t$ 関係の試験結果と 解析結果の比較を以下に示す。 3 . 2 節でも述べたように、提案し た復元力モデルは、静的に一定荷重を与えた場合にはひずみは時間 とともに変化せず一定であり、表 3 の加力条件では動的加力が止ま る 2 時間後以降は、クリープ特性を示さない。そのため、残留変形 の評価ができないため、加力 2 時間後までを比較した。図 13 からわ かるように、 $\tau_{\mathrm{s}} \pm \tau_{\mathrm{d}}=0.4 \pm 0.4 \mathrm{MPa}$ を除いて解析モデルの結果と実験結 果が高い精度で合致し、クリープ変形も再現できていることがわか る。一方、図 14 からわかるように、応答波加力試験との比較におい ては、風荷重がピークとなる間までは実験結果と解析結果が概㸚合 っている。しかしながら、風が弱まるにつれて実験結果の方が、せ ん断ひずみが大きくなる傾向を示し、危険側の評価となっている。 最終的な残留ひずみも実験結果の方が大きい結果となった。これは、 本解析モデルが面圧の影響を考慮していないことが原因の一つと考 えられる。実際の実験においても、試験終了後に積層ゴムの鉛直荷 重を除荷した瞬間に、残留変形が小さくなる現象が観測されており、 面圧の影響が大きいことを示している。表 8 に最大変形量と残留ひ ずみについて、実験結果と解析結果の比較を示した。

表 8 最大変形量と残留ひずみにおける 実験結果と解析結果の比較

\begin{tabular}{|c|c|c|c|}
\hline \multicolumn{2}{|c|}{} & 最大せん断ひずみ & 残留ひずみ \\
\hline \hline \multirow{2}{*}{ X-III } & 実験 & 0.72 & 0.23 \\
\cline { 2 - 4 } & 解析 & 0.80 & 0.15 \\
\hline \multirow{2}{*}{ X-II } & 実験 & 1.18 & 0.47 \\
\cline { 2 - 4 } & 解析 & 1.24 & 0.29 \\
\hline
\end{tabular}

本解析モデルにて、高減衰積層ゴムの風荷重応答解析を実施する ことにより、概ね最大変形を予測できると考えられる。ただし、残 留ひずみが過小評価になることに注意が必要である。また、急激な 温度上昇が生じるような場合も変形が過小評価となるため、本解析 モデルの適用範囲にも注意が必要である。 


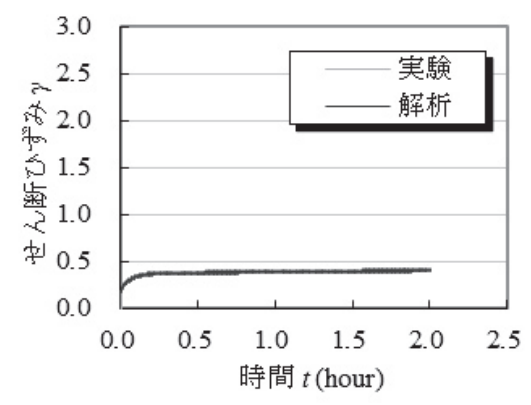

(a) $\tau_{\mathrm{s}} \pm \tau_{\mathrm{d}}=0.2 \pm 0.05$

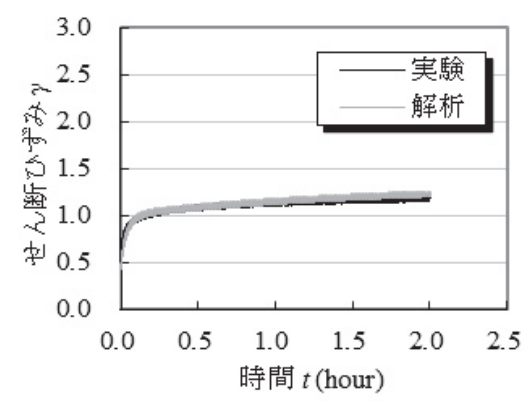

(d) $\tau_{\mathrm{s}} \pm \tau_{\mathrm{d}}=0.4 \pm 0.1$

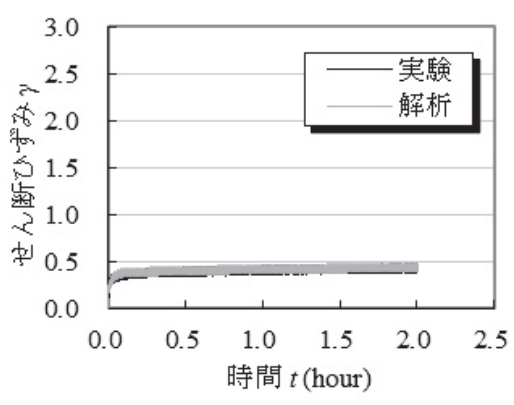

(b) $\tau_{\mathrm{s}} \pm \tau_{\mathrm{d}}=0.2 \pm 0.1$

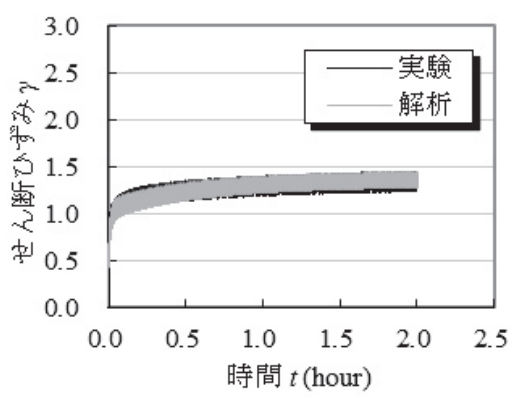

(e) $\tau_{\mathrm{s}} \pm \tau_{\mathrm{d}}=0.4 \pm 0.2$

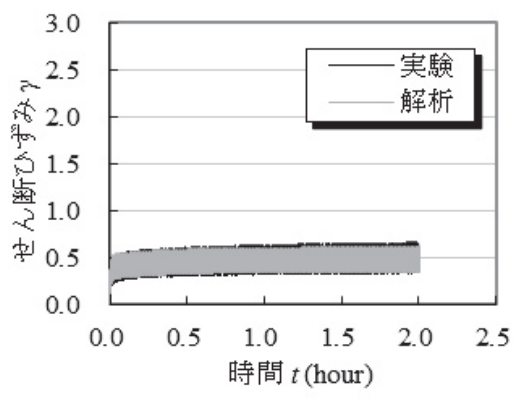

(c) $\tau_{\mathrm{s}} \pm \tau_{\mathrm{d}}=0.2 \pm 0.2$

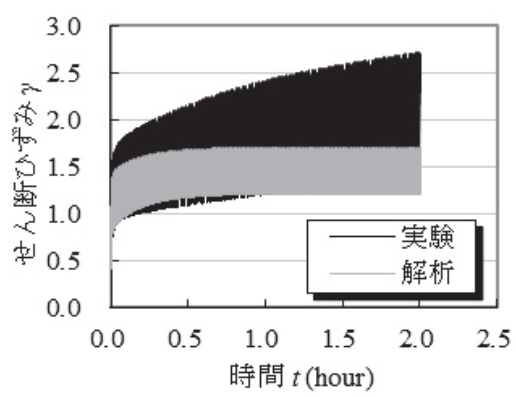

(f) $\tau_{\mathrm{s}} \pm \tau_{\mathrm{d}}=0.4 \pm 0.4$

図 13 動的加力試験における $\gamma-t$ 関係

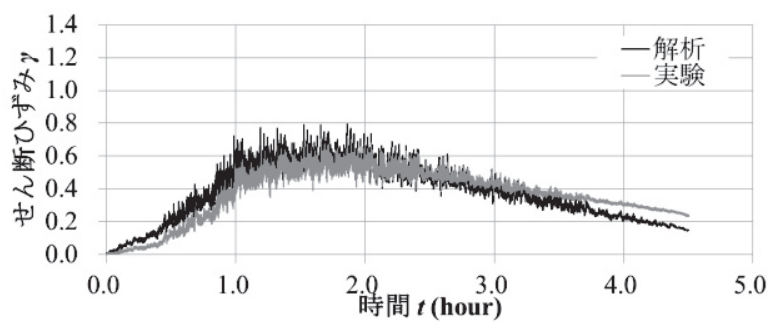

(a) X-III

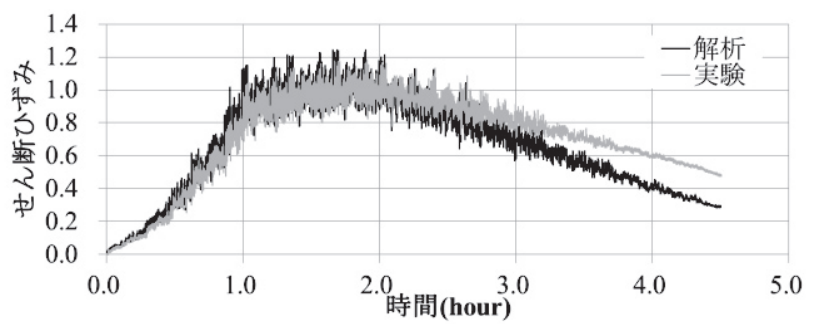

(b) X-II

図 14 応答波加力試験における $\gamma-t$ 関係

1 方向風応答における試験結果と比較し、本研究にて提案した復 元力モデルにて、高減衰積層ゴムの変形特性は概ね再現できること を確認した。先にも述べたとおり、風荷重は風向直交方向の影響が 問題となることもあり、水平 2 方向変形における評価が必要である。 復元力モデルも水平 2 方向加力を考慮したモデルが望ましい。そこ で、風荷重時刻歴応答解析の水平 2 方向応答荷重の結果を、 2 方向 を考慮した復元力モデル式(3.4)〜 (3.6)に入力し、 1 方向の場合との 比較を行った。物性パラメータは表 7 のものを用いた。応答波は、 1 方向の場合と同様に、鋁挿入型積層ゴムを想定した粗度区分 II の 風荷重時刻歷応答解析の応答荷重の結果を用いた 11 。風向方向の応 答波は図 $2(\mathrm{~b})$ と同一であり、風向直交方向の応答波は図 15 に示し た。図 14 と図 16 の比較からわかるように、残留変形については、 水平 1 方向と水平 2 方向の場合で差が見られなかった。しかしなが ら、水平 1 方向における最大変形と水平 2 方向における最大変形を 比較すると、水平 2 方向の方がせん断ひずみで $20 \%$ 程度、変形が大
きいことがわかる。以上は、解析による結果ではあるが、風荷重を 考慮した免震設計の場合には、水平 2 方向加力の影響の重要性が示 唆され、実験による水平 2 方向の風応答評価の実施も今後の課題で ある。

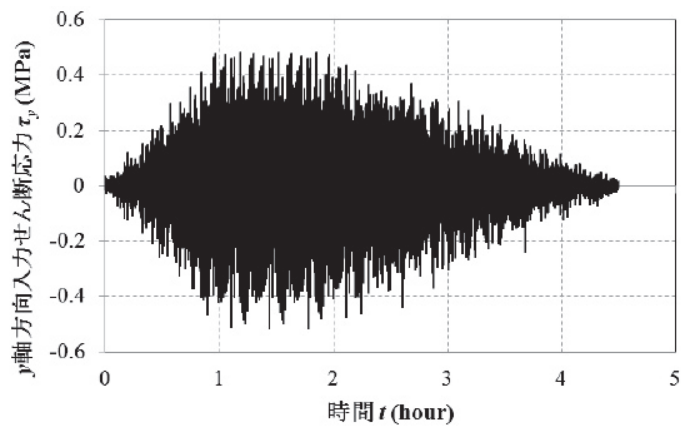

図 $15 \mathrm{X}-\mathrm{II}$ における風向直交方向の応答波 


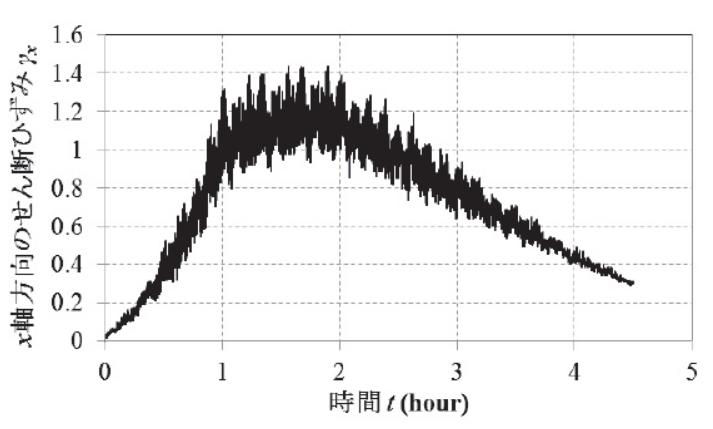

(a) $\gamma_{x}-t$ 関係(風向方向)

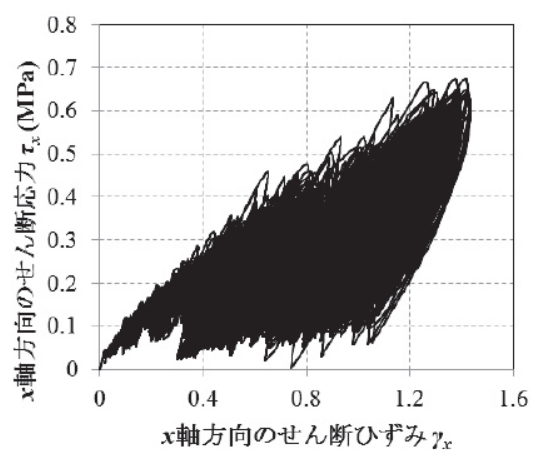

(c) $\tau_{x}-\gamma_{x}$ 関係(風向方向)

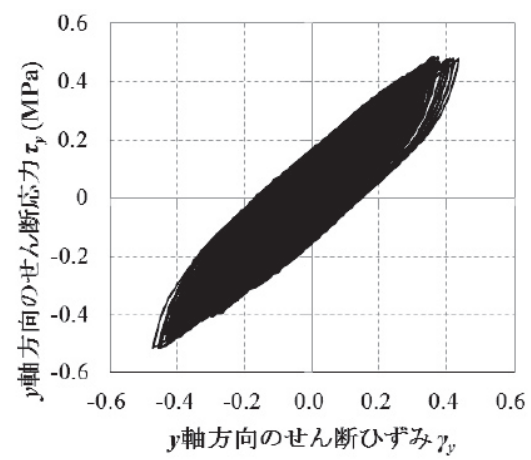

(d) $\tau_{\mathrm{y}}-\gamma_{\mathrm{y}}$ 関係(風向直交方向)

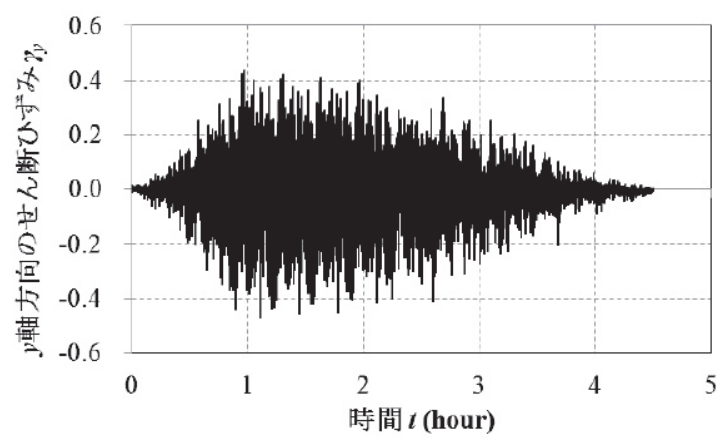

(b) $\gamma_{\mathrm{y}}-t$ 関係(風向直交方向)

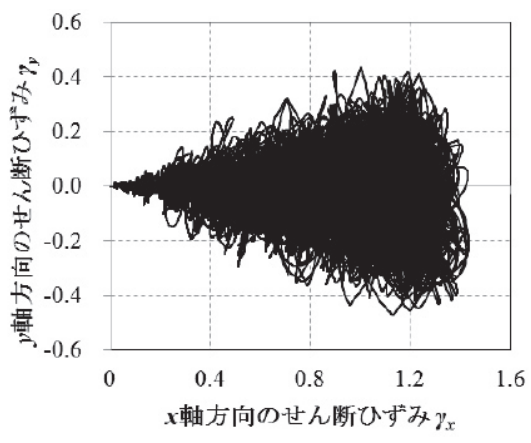

(e) 変形軌道

図 162 方向復元力モデルによる解析結果(X-II)

\section{4 風荷重時刻歴応答解析}

本節では、3．2 節にて検討した高減衰 2 方向復元力モデルを用 いた風荷重時刻歴応答解析を実施し、高減衰積層ゴムの挙動予測を 行う。ここでは、 1 質点系の水平 2 方向加力モデルを用いた。想定 した建物は、建築物荷重指針・同解説 $(2004)^{14)}$ の「風荷重の算出例 $2 」$ に示されている超高層建物を基本としている。ただし、建物の長手 方向が NS 方向と一致し、建物は平地に立地しているという簡略化 を施している。建築物の概要を表 9 に、建築物の形状を図 17 に示寸。

図 17 からわかるように、風向方向は方位 $\mathrm{W}$ 方向とし、風向方向を $\mathrm{x}$ 方向(EW 方向)、風直交方向を $\mathrm{y}$ 方向(NS 方向)とした。風の継続時 間は 5 時間とした。風力は、最初の 2 時間で線形に増大した後、1 時間のピークに達し、その後の 2 時間で線形に弱まるとした。免震 装置については、2 章の実験評価に用いたものと同じゴム種の積層 ゴムとし、積層ゴムの面圧を $15 \mathrm{MPa}$ 、積層ゴムのゴム総厚を $200 \mathrm{~mm}$ とした。以上の条件下で、本研究の 1 質点系モデルの固有周期は、 変形 $200 \mathrm{~mm}$ (積層ゴムのせん断ひずみ $\gamma=1$ )の場合に $4.4 \mathrm{sec}$ である。 復元力モデルのパラメータは表 7 のものを用いている。

表 9 想定した建築物の概要

\begin{tabular}{|l|l|}
\hline 建築物重量 & $180 \mathrm{~kg} / \mathrm{m}^{3}$ \\
\hline 建築地 & 東京都 B 区 $($ 基本風速 $: 36 \mathrm{~m} / \mathrm{sec})$ \\
\hline 粗度区分 & $\mathrm{I}$ \\
\hline 設計用再現期間 & 500 年 \\
\hline & $\mathrm{x}$ 方向 $: 0.30 \mathrm{~Hz}$ 、振動モード $\mu(Z)=(Z / H)^{0.9}$ \\
1 次固有振動数 & $\begin{array}{l}\mathrm{y} \text { 方向 }: 0.33 \mathrm{~Hz} \text { 、振動モード } \mu(Z)=Z / H \\
(Z: \text { 地表面からの高さ、 } H: \text { 建物の基準高さ) }\end{array}$ \\
\hline 1 次減衰定数 & $\mathrm{x}$ 、y 方向 $: 0.01$ \\
\hline
\end{tabular}

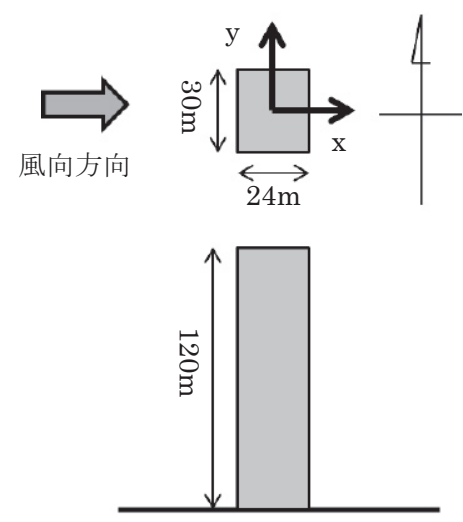

図 17 建物の形状及び風方向

入力風荷重波は、以下の手順に従って作成した。

(1)「建物荷重指針・同解説(2004)」の構造骨組用水平荷重の算出法 に従い、風向方向の風荷重 $W_{\mathrm{x}}$ 及び風向直交方向の風荷重 $W_{\mathrm{y}}$ を 算出する。

(2) (1)で算出した風荷重から、風向方向の風応力の静的成分 $\tau_{\mathrm{sx}}$ と動 的成分 $\tau_{\mathrm{dx}}$ 及び風向直交方向の風応力の動的成分 $\tau_{\mathrm{dy}}$ を以下の通 り規定する。 $A$ は全ての積層ゴムの有効断面積の総和、 $G_{\mathrm{D}}$ は (1) で風荷重の導出過程で算出されるガスト影響係数である。

$\left\{\begin{array}{l}\tau_{\mathrm{sx}}=W_{\mathrm{x}} /\left(A G_{\mathrm{D}}\right) \\ \tau_{\mathrm{dx}}=W_{\mathrm{x}} / A-\tau_{\mathrm{sx}} \\ \tau_{\mathrm{dy}}=W_{\mathrm{y}} / A\end{array}\right.$

(3) (2)で算出した $\tau_{\mathrm{sx}} 、 \tau_{\mathrm{dx}} 、 \tau_{\mathrm{dy}}$ の值をもとに、表 10 に示した条件で、 入力波を生成する。以上の仮定のみでは、詳細な波形の予測は 非常に困難なため、波形はホワイトノイズを仮定する。具体的 
には、ボックスーミュラー法によって正規乱数を 2 秒おきに発生 させ、それらのポイント間を線形補完し、表 10 の条件を満たす ように規格化することで波形を生成する。ただし、風向方向の 風荷重は、上限值 $\tau_{\mathrm{sx}}+\tau_{\mathrm{dx}}$ と下限值 0 を超えない範囲とし、風向 直交方向の風荷重は、上限值 $+\tau_{\mathrm{dy}}$ と下限值 $-\tau_{\mathrm{dy}}$ を超えない範囲と する。

表 10 入力風荷重波の条件

\begin{tabular}{|c|l|l|}
\hline \multirow{2}{*}{ 風向方向 } & 静的成分 & $F(t) \tau_{\mathrm{sx}}$ \\
\cline { 2 - 3 } & 動的成分 & $\begin{array}{l}\text { 変動幅 }(\mathrm{RMS})=F(t) \tau_{\mathrm{dx}} / 3(\mathrm{MPa}) \text { ホワイトノイズ } \\
\text { ホワト }\end{array}$ \\
\hline $\begin{array}{c}\text { 風向直交 } \\
\text { 方向 }\end{array}$ & 静的成分 & 0 \\
\cline { 2 - 3 } & 動的成分 & $\begin{array}{l}\text { 変動幅 }(\mathrm{RMS})=F(t) \tau_{\mathrm{dy}} / 3(\mathrm{MPa}) \text { ホワイトノイズ } \\
\text { ホワイ }\end{array}$ \\
\hline
\end{tabular}

※ $F(t)$ は風力の時間変化を表寸関数であり、以下で定義される。 $t$ は経過 時間(hour)である。

$$
\begin{cases}F(t)=0.5 \times t & (0 \leq t<2) \\ F(t)=1 & (2 \leq t<3) \\ F(t)=2.5-0.5 \times t & (3 \leq t \leq 5)\end{cases}
$$

以上の計算条件から算出された $\tau_{\mathrm{sx}} 、 \tau_{\mathrm{dx}} 、 \tau_{\mathrm{dy}}$ の值は、それぞれ、 $\tau_{\mathrm{sx}}=0.327(\mathrm{MPa}) 、 \tau_{\mathrm{dx}}=0.465(\mathrm{MPa}) 、 \tau_{\mathrm{dy}}=0.547(\mathrm{MPa})$ となった。作成され た入力波を、図 18 に示す。数值解析には 4 次の Runge-Kutta 法を用 い、時間刻みは $\Delta t=0.001 \mathrm{sec}$ とした。

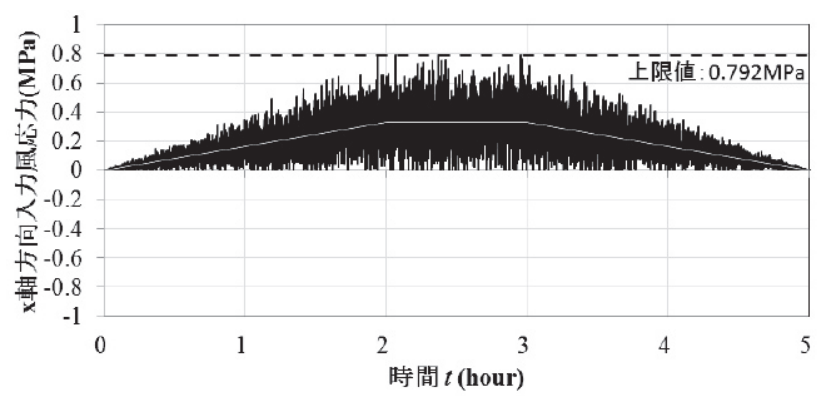

(a) $\mathrm{x}$ 方向(風向方向)

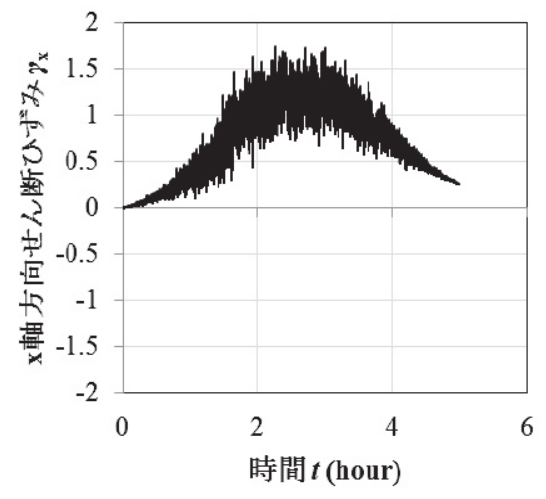

(a) $\gamma_{x}-t$ 関係(風向方向)

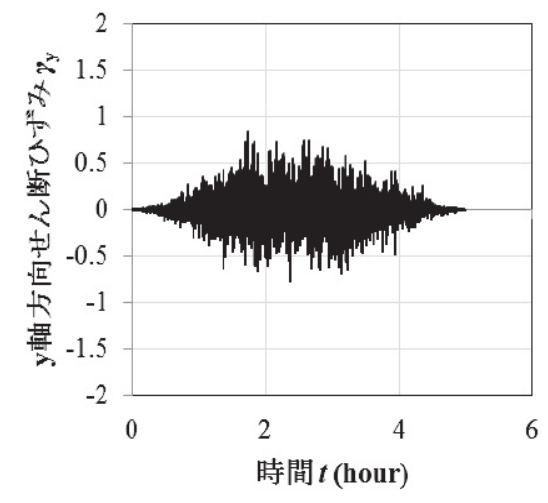

(b) $\gamma_{\mathrm{y}}-t$ 関係(風向直交方向)

図 19 時刻歴応答解析結果

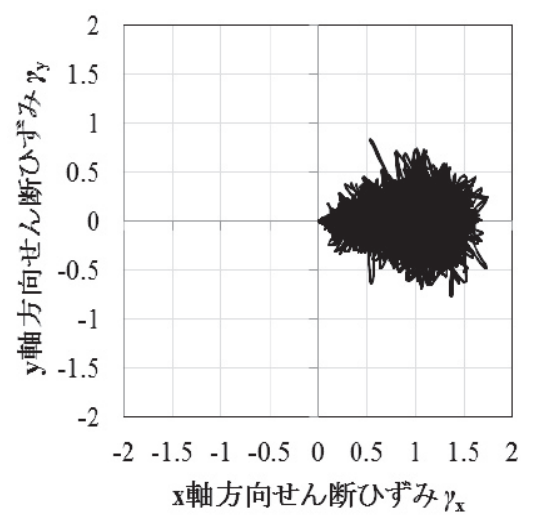

(c) 変形軌道
時刻歷応答解析結果を図 19 に、風向方向のせん断ひずみ $\gamma_{\mathrm{x}}$ 、風向 直交方向のせん断ひずみ $\gamma_{\mathrm{y}}$ 及び 2 方向におけるせん断ひずみ $\left(\gamma_{x}^{2}+\gamma_{y}^{2}\right)^{1 / 2}$ の、最大值と残留ひずみの結果を表 11 に示す。3．3 節 で提案した簡易評価式において、 $\tau_{s} 、 \tau_{\mathrm{d}} 、 t$ にそれぞれ風向方向の静

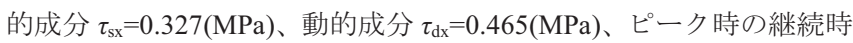
間 $t=1$ (hour)を代入した場合、最大せん断ひずみは 1.91 となる。風向 方向のみに着目寸れば、時刻歷応答の結果における最大せん断ひず みは予測式よりも小さい 1.75 であり、簡易評価式の結果が安全側の 評価となっていることがわかる。しかしながら、2 方向を考慮した 場合、最大せん断ひずみは予測式の值 1.91 を上回り、1.94 という結 果となった。入力波形の予測の困難さから、本論文ではホワイトノ イズを仮定した風荷重を用いている。その妥当性は別途検討が必要 だが、以上の結果から、風向直交方向の影響も無視できず、2 方向 を考慮することの重要さが理解される。

表 11 時刻歴応答解析における最大せん断ひずみと残留ひずみ

\begin{tabular}{|c|c|c|}
\hline & 最大せん断ひずみ & 残留ひずみ \\
\hline \hline 風向方向 $(\mathrm{x}$ 方向 $)$ & 1.75 & 0.16 \\
\hline 風向直交方向 $(\mathrm{y}$ 方向 $)$ & 0.84 & 0.00 \\
\hline$\left(\gamma_{\mathrm{x}}{ }^{2} \gamma_{\mathrm{y}}{ }^{1 / 2}\right.$ & 1.94 & 0.16 \\
\hline
\end{tabular}

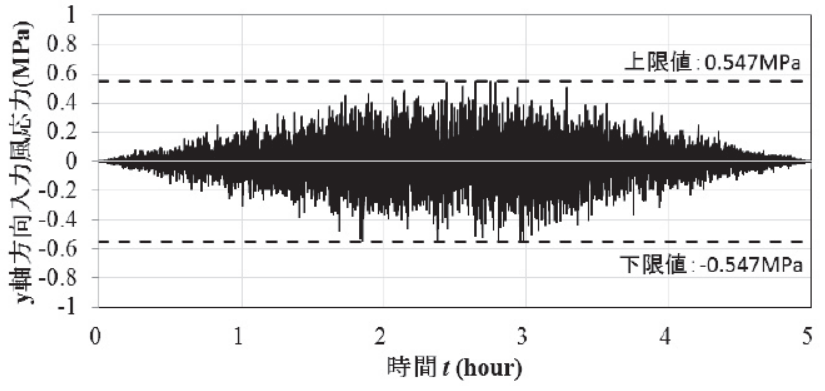

(b) y 方向(風向直交方向)

図 18 入力波形 


\section{4.まとめ}

高減衰積層ゴムにおける風応答特性の評価試験を実施した。一般 に復元力と減衰性能を併せ持つ免震装置は、一定荷重を与えた場合 にクリープ変形を示す。風応答評価試験の結果、高減衰積層ゴムの クリープ特性は風荷重の静的成分だけでなく、動的成分にも依存す ることがわかった。即ち、静的成分を一定とし、動的変動成分を様々 に変化させた場合のクリープ特性を調べると、動的変動成分が大き い程、積層ゴムの水平変形が大きくなる性質を示すことが明らかと なった。また、動的な繰り返し加力によるエネルギー吸収によって、 積層ゴムの内部温度が急激に上昇するような場合には、水平変形が 急激に増大寸る不安定現象が確認された。

実験によって確認された動的クリープ変形を考慮し、高減衰積層 ゴムの風荷重下の最大せん断ひずみを予測する簡易評価法及び時刻 歴応答解析を目的とした復元力モデルを提案した。また、実験結果 と比較することで、簡易評価式及び復元力モデルの妥当性について 検証した。温度上昇による不安定挙動を示寸場合を除き、簡易評価 式及び復元力モデルともに、概ね試験結果を再現できることを確認 した。しかしながら、温度上昇の影響は積層ゴムの変形特性に大き な影響を与えることも実験から明らかである。今後は温度上昇の影 響を考慮した復元力モデルの構築が課題の一つである。また、本研 究における復元力モデルは、残留変形が過小評価になり、2 章の実 験結果で示されたような、除荷後に残留変形が小さくなるクリープ 特性も再現できない。今後は、除荷後の特性も含めて残留変形の予 測が可能な復元力モデルの構築が課題である。

\section{謝辞}

本研究中にある実験・解析に用いた風荷重応答波形は基準整備事 業 12 「免震建物の基準の整備に資する検討」の成果に基づき実施し ています。データ提供にあたり、鹿島建設株式会社、竹中康雄氏、 近藤明洋氏にご尽力および多くの助言をいただき、ここに謝意を表 します。また、東京理科大学北村春幸教授、日本大学神田亮教授、 北海道大学菊地優教授には、本研究に対する貴重な助言に心より感 謝いたします。

\section{参考文献}

1) 仲村崇仁, 竹中康雄, 池永雅良, 鈴木雅靖, 河内山修, 吉川和秀, 金子修 平：高層免震建物の風応答における LRB の健全性に関する研究(その 1 ２), 日本建築学会大会学術講演梗概集 B, pp.489-492, 2003.9

2) 河内山修, 仲村崇仁, 金子修平, 和田章 : 風応答における高層免震建物の LRB の健全性評価, MENSHIN, 47, pp.47-53, 2005.2

3) 竹中康雄, 飯塚真巨, 鈴木雅靖, 吉川和秀, 山田和彦 : 鉛プラグ型積層ゴ ムのクリープ性を考慮した高層免震建物の風応答簡易評価法, 日本建築 学会構造系論文集, 第 561 号, pp.89-94, 2002.11

4) 鈴木雅靖, 上野薰, 竹中康雄, 吉川和秀, 鈴木重信 : 高層免震建物の台風 時における免震装置に関する動的加力実験, 風工学シンポジウム論文集 16 , pp.417-422, 2000.12

5) 竹中康雄，菊地隆志，鈴木雅靖，飯塚真巨，山田和彦，吉川和秀，二村有 則, 鈴木重信 : 高層免震建物の風応答に関寸る研究(その $2 \sim 3$ ), 日本建築 学会大会学術講演梗概集 B, pp.677-680, 2001.9

6) 加藤秀章, 森隆浩, 室田伸夫 : 高減衰系積層ゴムの風荷重応答に関する積 層ゴム加力実験 (その $1 \sim 2$ ), 日本建築学会大会学術講演梗概集 $\mathrm{B}$, pp.817-820, 2009.8

7) 安井八紀, 大熊武史, 丸川比佐夫 : クリープ変形を伴う免震建物の風応答 性状に関する研究, 日本建築学会構造系論文集, 第 619 号, pp.41-48, 2007.9

8) 森隆浩, 加藤秀章, 室田伸夫 : 変形履歴積分型の弾塑性構成則を用いた高 減衰積層ゴムの FEM 解析, 日本建築学会構造系論文集, 第 75 巻, 第 658 号, pp.2171-2178, 2010.12

9) 森隆浩, 加藤秀章, 竹内貞光, 菊地隆志, 室田伸夫 : 風荷重の動的成分が 高減衰系積層ゴムの応答特性に与える影響に関する実験的研究及び解析 モデルの検討, 日本建築学会構造系論文集, 第 77 巻, 第 676 号, pp.1721-1728, 2011.9

10)「高減衰積層ゴム(X0.6R タイプ)技術資料」，侏ブリヂストン, 2011.5

11) 鈴木雅靖, 竹中康雄, 近藤明洋, 飯場正紀, 大熊武司, 松井正宏, 安井八 紀, 吉江慶祐 : 高層免震建物の風応答時刻歴解析による検討(その $1 \sim 2$ ), 日本建築学会大会学術講演梗概集 B, pp.277-280, 2010.9

12）鈴木雅靖，近藤明洋，竹中康雄，飯場正紀，大熊武司，松井正宏 : 高層免 震建物の風応答時刻歴解析による検討(その 3 4), 日本建築学会大会学 術講演梗概集 B, pp.613-616, 2011.8

13) 菊地隆志, 竹内貞光, 森隆浩, 加藤秀章, 室田伸夫 : 高減衰ゴム系積層ゴ 厶支承における風荷重の研究(その 1 2), 日本建築学会大会学術講演梗 概集 B, pp.513-516, 2011.8

14) 日本建築学会 : 建築物荷重指針・同解説，丸善, 2004

(2011年 9 月 8 日原稿受理, 2012年 2 月 23 日採用決定) 